\title{
UNSUR KONFLIK DALAM NOVEL NENEK KARYA RAZALI ENDUN
}

\section{(Conflict Elements in Nenek Novel by Razali Endun)}

\author{
Rosnani Md Zain \\ nanieyzain@gmail.com \\ Nik Rafidah Nik Muhamad Affendi \\ nikrafidah@gmail.com
}

Fakulti Bahasa Moden dan Komunikasi,
Universiti Putra Malaysia.

Published on: 1 June 2018

To cite: Rosnani Md Zain and Nik Rafidah Nik Muhamad Affendi. (2018). Unsur konflik dalam novel Nenek karya Razali Endun. Malay Literature 31(1), 124-142

\begin{abstract}
Abstrak
Makalah ini membicarakan konflik yang terdapat dalam novel Nenek. Novel ini memenangi Hadiah Sastera Perdana Malaysia pada tahun 2014. Kemenangan novel Nenek mencetuskan kontroversi kerana ada pihak yang tidak bersetuju novel tersebut diangkat sebagai pemenang. Objektif kajian ini adalah untuk mengklasifikasi dan menganalisis unsur konflik yang terdapat dalam novel Nenek dari perspektif humanistik Abraham Maslow. Novel ini memaparkan kisah manusia yang sering bertelagah dan berada dalam situasi dilema dan tidak dapat membuat keputusan yang tepat bagi menyelesaikan masalah. Mereka berhadapan dengan konflik untuk meleraikan masalah yang membelenggu hidup mereka. Konflik yang berlaku kepada watak-watak akhirnya dapat ditangani oleh mereka dengan bijak. Daripada penelitian, novel Nenek menyentuh beberapa aspek konflik seperti konflik individu, politik, ekonomi dan keluarga. Kajian mendapati Razali Endun berjaya memberikan gambaran tentang masyarakat kontemporari berdasarkan paparan konflik semasa dalam novelnya.
\end{abstract}


Kata kunci: Nenek, Hadiah Sastera Perdana 2014, konflik, humanistik Maslow

\begin{abstract}
This article discusses the conflict found in the novel Nenek. Nenek won the prestigious Hadiah Sastera Perdana literary prize in 2014. The novel sparked controversy when it was declared the winner. Critics felt that Nenek did not meet the criteria and was awarded the prize due to political interference. The objective of this study is to classify and analyse elements of conflict in Nenek. This study will look at conflicts in the novel from the perspective of the humanistic psychologist Abraham Maslow. Humans are never free of problems. These problems and conflicts cause people to struggle, and they are in a constant state of dilemma where they are unable to make the right decisions and solve problems. Human beings are forced to deal with conflicts to disperse the problems that upset their lives instead of avoiding them. In the end, conflicts involving the characters are handled wisely. The study finds that Nenek touches on several types of conflict, such as political conflicts, economic conflicts and family conflicts. The study shows that Razali Endun is able to depict contemporary society by depicting such conflicts in his novels.
\end{abstract}

Keywords: Nenek, Hadiah Sastera Perdana 2014, conflict, Maslow Humanistic

\title{
PENGENALAN
}

Konflik merupakan sesuatu yang tidak asing lagi dalam kehidupan manusia dan sentiasa melingkari kehidupan mereka. Menurut Nor Ruadhah (2006, p. 46), manusia tidak pernah terlepas daripada menghadapi konflik, sama ada konflik dalaman atau konflik luaran. Konflik membentuk kehidupan manusia sama ada tenang, berkocak, bahagia atau berdukacita. Konflik tidak seharusnya dilihat dari sudut negatif sahaja. Dari sudut positif, konflik boleh menyelesaikan sesuatu masalah yang dihadapi. Hal ini kerana konflik yang timbul kadangkala dapat menyelesaikan sesuatu masalah. Konflik yang berlaku dalam kehidupan menjadikan manusia lebih matang dalam membuat sesuatu keputusan. Perbezaan pendapat merupakan faktor utama tercetusnya sesuatu konflik. Hal ini bersesuaian dengan pendapat Fatimah Daud (1992, p. 36), mengatakan bahawa konflik merujuk perselisihan faham atau pendapat dan salah faham, tiada muafakat atau sepakat, tidak setuju dalam mencapai tujuan tertentu, menyimpang daripada motivasi tertentu atau keberatan untuk melakukan sesuatu. Di samping itu, Ting (1997, p. 67) berpendapat 
bahawa konflik merupakan pertentangan secara langsung dan sedar antara individu atau kumpulan untuk mencapai matlamat bersama. Kerap kali dalam persaingan, kekalahan pihak lawan amat diutamakan daripada pencapaian matlamat. Konflik secara umumnya bermaksud pertentangan, perbezaan, perselisihan, pergaduhan, ketidaksamaan, ketidakselarasan dan peperangan (Azizi dan Jaafar Sidek 2006, p. 209).

Dilihat dari sudut psikologi, konflik dianggap sebagai situasi apabila dua atau lebih keperluan, matlamat atau tindakan yang tidak boleh seiring bertanding antara satu sama lain. Keadaan ini menyebabkan organisma berasa ditarik dari pelbagai arah dan berasa tidak selesa (Asmawati, 2002, p. 274). Dari sudut psikologi, konflik dilihat sebagai tingkah laku yang dialami oleh individu seperti yang dijelaskan oleh Mohd. Foad Sakdan (2005, p. 2) merupakan sifat semula jadi manusia yang sentiasa bersama dan berkembang secara dinamik seiring dengan perkembangan manusia yang boleh dianalisis melalui tingkah laku dan personaliti seseorang.

Dari sudut psikologi konflik biasanya diklasifikasikan dalam bentuk nilai ganjaran atau hukuman pada pilihan yang dihadapi oleh seseorang itu (Mahmood Nazar, 1990, p. 352). Dalam konteks kajian ini, Nik Rafidah (2016:1) mengatakan bahawa sastera dan psikologi tidak dapat dipisahkan. Dua bidang yang berbeza tetapi mempunyai satu titik temu yang sama. Kedua-duanya berbicara tentang manusia dan kehidupannya. Berdasarkan pandangan tokoh tersebut tentang definisi konflik dapat dijelaskan bahawa konflik merupakan sifat semula jadi manusia yang berselisih pendapat bagi mencapai sesuatu matlamat. Konflik bukannya sesuatu gejala yang harus dihindari kerana kadangkala konflik boleh menyelesaikan masalah yang dialami oleh seseorang atau anggota masyarakat. Sehubungan dengan itu, makalah ini akan membincangkan unsur konflik yang terdapat dalam novel Nenek yang dilihat dari perspektif humanistik Abraham Maslow.

\section{PENYATAAN MASALAH}

Pengkajian Kajian terhadap genre novel memang tidak asing lagi dalam kalangan sarjana Barat dan tempatan. Genre novel ini mendapat perhatian ramai kerana terdapat pelbagai skop yang menarik untuk diterokai. Sifat karya sastera yang subjektif dan terbuka kepada pelbagai interpretasi menyebabkan banyak sekali pertikaian yang mungkin wujud apabila sesuatu karya itu diangkat tidak kira sama ada dalam pertandingan mahupun sebagai teks 
kajian. Persoalan di sini sama ada novel yang telah dipilih itu sememangnya sesuai dan mudah dibaca, atau sebaliknya.

Novel Nenek karya Razali Endun telah diangkat sebagai pemenang Hadiah Sastera Perdana Malaysia 2014. Namun begitu, novel ini dianggap tidak layak menang oleh segelintir pihak. Golongan tersebut menganggap novel Nenek memaparkan konflik yang sederhana dan tidak mencabar keintelektualan khalayak pembaca. Lantaran itu, ada juga pihak yang mengatakan kemenangan novel tersebut disebabkan oleh pengaruh politik.

Namun demikian, berdasarkan penelitian pengkaji terdapat juga pihak yang menyokong akan kemenangan tersebut. Antaranya termasuklah Disman yang menyatakan bahawa walaupun kemenangan novel Nenek di luar dugaan, namun beliau mengakui novel tersebut antara novel penting yang dilahirkan beberapa tahun kebelakangan ini. Beliau menambah, Nenek merupakan sebuah novel yang menyorot hal kemanusiaan tanpa mengenal bangsa. Beliau turut mengakui bahawa Nenek merupakan novel terbaik karya Razali Endun setakat ini walaupun tidak sekompleks Salina atau Saudagar Besar dari Kuala Lumpur. Konflik yang diketengahkan oleh Razali Endun amat dekat dengan masyarakat dan isu tersebut merupakan masalah yang melanda masyarakat kebelakangan ini (Dewan Sastera, 2016). Selain itu, Mohd Nasir Hashim juga menyokong kemenangan novel Nenek. Beliau berpendapat latar tempat dan konflik sosial yang diungkapkan dalam novel Nenek dapat dilihat dari dimensi yang lebih menyeluruh. Konflik yang diketengahkan dalam novel Nenek merupakan penyataan sosial yang wujud dalam masyarakat pada hari ini yang telah menghancurkan nilai kemanusiaan serta lebih mementingkan kapitalisme (Dewan Sastera, 2016). Kemenangan tersebut juga disokong oleh Ahli Panel Penilai HSPM yang menegaskan bahawa Razali Endun berjaya meneroka konflik masyarakat yang mencakupi pemasalahan politik, ekonomi dan sosial dengan bahasa yang sederhana serta gaya penceritaan yang realistik (Dewan Sastera, 2016).

Berdasarkan isu yang ditimbulkan, pengkaji telah terpanggil untuk melihat penyataan pro dan kontra tentang novel Nenek terutama dari aspek konflik. Sehubungan dengan itu, kajian ini cuba melihat konflik yang diketengahkan oleh pengarang dari pelbagai aspek dalam kehidupan masyarakat. Percanggahan pendapat antara ahli akademik, penulis novel dan pengkritik sastera mendorong pengkaji untuk membuat kajian lanjut terhadap novel Nenek karya Razali Endun.

Kajian yang dijalankan ini bertujuan untuk mengklasifikasikan unsur konflik yang terdapat dalam novel Nenek, dan menganalisis unsur konflik 
yang terdapat dalam novel Nenek berdasarkan perspektif humanistik Abraham Maslow.

\section{METODOLOGI KAJIAN}

Dalam kajian ini, pengkaji telah memilih kaedah kajian kualitatif. Menurut Bogdan dan Taylor dalam Moleong (2004, p. 4) kaedah kualitatif ialah prosedur penelitian yang menghasilkan data deskriptif yang berupa katakata bertulis atau lisan daripada orang yang berperilaku dan perilaku yang diperoleh. Sehubungan dengan itu, dalam kajian ini reka bentuk kajian yang digunakan ialah kaedah kajian kepustakaan, kajian analisis teks dan penerapan teori humanistik Abraham Maslow.

Seterusnya, teori humanistik Maslow (1970) digunakan untuk melihat manusia sebagai insan yang baik serta mulia, dan mempunyai dorongan semula jadi seterusnya mencapai kesempurnaan kendiri. Menurut beliau lagi, manusia mempunyai kehendak semula jadi yang sedia ada dalam diri, dan kehendak ini wujud dalam bentuk hierarki yang mempunyai keutamaan masing-masing. Dalam bukunya bertajuk Motivation and Personality (1970, pp. 35-47), Maslow telah menjelaskan bahawa keperluan manusia terbahagi kepada lima tahap yang utama, iaitu keperluan fisiologi, keperluan keselamatan, keperluan kasih sayang dan dipunyai, keperluan penghargaan diri dan keperluan penyempurnaan kendiri.

Menurut Maslow (1970, p. 35), keperluan fisiologi merupakan asas yang utama disarankan dalam teori ini. Pada tahap ini, Maslow telah menegaskan bahawa tahap ini harus dipenuhi terlebih dahulu sebelum memenuhi kehendak-kehendak yang lain. Dalam hal ini jelas membuktikan bahawa manusia memerlukan beberapa perkara asas bagi meneruskan kelangsungan hidup seperti makanan, minuman, tempat tinggal dan pakaian. Jelaslah di sini bahawa manusia perlu memenuhi kesemua tuntutan fisiologi seperti yang telah digariskan oleh Maslow sebelum melangkah ke tahap seterusnya.

Peringkat kedua ialah jaminan keselamatan. Manusia memerlukan jaminan keselamatan bagi meneruskan kelangsungan hidup. Bentuk keselamatan yang diperlukan oleh manusia pada peringkat ini ialah keselamatan fizikal, kestabilan politik, ekonomi, mendapat perlindungan undang-undang, kebebasan bersuara, tidak berada dalam ketakutan, bimbang dan perasaan tidak menentu. Tegasnya, manusia ingin memastikan bahawa dirinya berada dalam suasana yang terjamin, persekitaran yang stabil, konsisten dan selamat. Aspek keselamatan juga merangkumi keselamatan 
mental dan spiritual. Rasa tenang, bimbang dan takut akan mengakibatkan manusia terikat pada kedudukan serta kerap mempamerkan sikap negatif. Akibatnya mereka sukar bergerak bagi mencapai kehendak-kehendak pada peringkat seterusnya.

Peringkat ketiga ialah keperluan kasih sayang. Maslow (1970, p. 43) mengatakan bahawa untuk memenuhi keperluan kasih sayang, manusia memerlukan hubungan dengan insan lain seperti ahli keluarga, sahabat, masyarakat dan sebagainya. Di samping itu, manusia juga ingin diterima oleh keluarga dan masyarakatnya. Untuk diterima oleh keluarga dan masyarakat, manusia akan berusaha bersungguh-sungguh untuk mencapai matlamat yang diingini, iaitu dengan melibatkan penerimaan orang di sekelilingnya.

Seterusnya, setelah mencapai tahap ini, manusia akan menuju ke tahap seterusnya, iaitu tahap keperluan penghargaan kendiri. Pada tahap ini, setiap manusia ingin dirinya dihargai atas segala pencapaian atau aktiviti yang telah dilakukan.

Sehubungan dengan itu, teori humanistik Maslow mampu menjelaskan keunikan setiap individu dan berjaya memperkenalkan kaedah bagi membantu masyarakat untuk mengenal potensi diri. Oleh hal yang demikian, konflik yang tercetus dalam masyarakat jika dilihat dari sudut yang positif merupakan cara untuk mengenal potensi diri. Seseorang yang menginginkan kehendak penghargaan kendiri juga memerlukan keperluan lain seperti fisiologi, keselamatan, kasih sayang dan rasa dicintai serta mencintai.

\section{DAPATAN KAJIAN}

Berdasarkan penelitian pengkaji, terdapat empat konflik yang dapat dikesan dalam novel Nenek karya Razali Endun, iaitu konflik kepimpinan politik, konflik keluarga, konflik ekonomi dan konflik individu.

\section{Konflik Kepimpinan Politik}

Definisi kepimpinan menurut pendapat Robiah (2004, p. 3) merupakan suatu bentuk hubungan apabila seseorang mempunyai kesempatan dan kemampuan untuk mempengaruhi perlakuan orang lain, melalui gerak laku, pemikiran, tutur kata, dan tindakannya. Proses kepimpinan tidak mungkin dapat dipisahkan daripada aktiviti kumpulan dan proses ini melibatkan peribadi serta ketokohan pemimpin, harapan orang yang dipimpin, suasana dan persekitaran serta matlamat yang hendak dicapai.

Bolman dan Deal (1984) dalam Mohammed Sani dan Jamalul Lail (2012, p. 35) telah menggariskan lima andaian yang menjadi asas orientasi 
rangka kepimpinan politik, iaitu organisasi terdiri daripada gabungan pelbagai individu dan kumpulan yang berkepentingan. Terdapat perbezaan nilai, kepercayaan, maklumat, minat dan persepsi terhadap realiti yang berterusan dalam kalangan gabungan ahli organisasi. Kebanyakan keputusan penting melibatkan pengagihan sumber yang terhad. Sumber yang terhad dan perbezaan berterusan menjadikan konflik dalam organisasi. Kuasa menjadi sumber utama serta matlamat. Keputusan terbentuk hasil daripada proses tawar-menawar, perundingan dan melobi dalam kalangan kumpulan yang berkepentingan untuk mendapatkan sesuatu jawatan.

Berdasarkan penelitian, novel Nenek karya Razali Endun (2014) mengungkapkan konflik kepimpinan politik. Konflik ini tercetus daripada sikap tamak segelintir pemimpin politik yang mementingkan diri sendiri. Pengaruh dan kuasa politik dijadikan landasan untuk menindas penduduk kampung. Oleh sebab sikap tamak serta mengejar kekayaan, segelintir pemimpin politik sanggup mengorbankan bangsa sendiri. Pelbagai strategi dan tipu muslihat digunakan untuk menindas golongan yang lemah, sedangkan pada hakikatnya, seorang pemimpin politik diamanahkan untuk menjaga keamanan dan kesejahteraan kawasan yang dipegangnya.

Hal ini dilihat melalui watak Tan Sri Dahan. Tan Sri Dahan merupakan pemimpin politik yang tidak menjalankan amanah untuk membela nasib rakyat. Bahkan Tan Sri Dahan menggunakan tipu muslihat bagi mendapatkan tanah penduduk kampung untuk dibangunkan sebagai kawasan industri. Sikap tamak Tan Sri Dahan menyebabkan orang kampung hilang pekerjaan, dan kemiskinan kian menghimpit mereka.

Tan Sri Dahan juga digambarkan sebagai seorang pemimpin yang suka mengamalkan rasuah. Rasuah dijadikan umpan untuk mendapatkan sesuatu yang diinginkan. Tan Sri Dahan memberikan rasuah RM10,000 kepada Dato' Mahfus bagi melicinkan pengurusan pengambilan tanah di bukit Kampung Bertam Malim. Selain wang, Tan Sri Dahan juga memberikan sebuah banglo, pangkat dan melantik Dato' Mahfus sebagai salah seorang Ahli Lembaga Pengarah Syarikat Padu Menang Sdn. Bhd. Pelbagai strategi diatur bagi menjayakan rancangan tersebut termasuklah memperjudikan agama. Konflik tersebut bermula dengan pemecatan imam Haji Khamis dan digantikan dengan imam Haji Kusnin. Haji Kusnin menerima jawatan tersebut kerana diugut oleh Dato' Mahfus. Tindakan licik Tan Sri Dahan tidak disedari oleh penduduk kampung. Tawaran pakej umrah secara percuma merupakan taktik yang digunakan oleh Tan Sri Dahan bagi menjerat penduduk kampung. Sesiapa yang menerima 
tawaran mengerjakan umrah secara automatik tanah mereka bertukar hak milik. Namun begitu, pihak pemaju tidak memberitahu penduduk kampung implikasi perjanjian tersebut.

Sikap buruk Tan Sri Dahan ditonjolkan oleh pengarang apabila dia memerangkap Dato' Mahfus dengan menunjukkan beberapa keping gambar Dato' Mahfus yang memegang sampul surat berisi wang RM10,000. Wang tersebut merupakan rasuah yang diberikan oleh Tan Sri Dahan kepada Dato' Mahfus. Bukan itu sahaja, Tan Sri Dahan menunjukkan sepucuk surat daripada jawatankuasa cawangan partinya tentang mesyuarat agung meluluskan usul tidak percaya kepada Dato' Mahfus. Terlibat sama dalam komplot tersebut ialah Megat Dewa dan Mad Dali. Dato' Mahfus juga dikenakan tindakan pecah amanah wang syarikat sedangkan wang peruntukan yang diberikan kepada penduduk kampung atas arahan Tan Sri Dahan.

Tan Sri Dahan juga digambarkan sebagai pemimpin yang mementingkan diri sendiri. Beliau sanggup mengorbankan masa depan bangsanya demi mendapatkan keuntungan. Pembangunan perumahan di kawasan tersebut menyebabkan pola penduduk bertukar wajah. Majoriti pemilik hartanah tersebut ialah bangsa Tionghoa. Hal ini menyebabkan pola penduduk menjadi tidak sekata. Penduduk asal kampung Bertam Malim tidak dapat menikmati erti pembangunan yang sebenar. Kemasukan warga asing yang tidak terkawal juga menjadi pesaing kepada penduduk kampung bagi mendapatkan peluang pekerjaan.Tanah yang asalnya merupakan tanah pertanian bertukar wajah menjadi kawasan perindustrian.

Pembangunan yang tidak terkawal menjejaskan pendapatan masyarakat yang kebanyakannya bertani sawah. Kesan yang lebih buruk lagi kerana kelemahan kepimpinan Melayu ialah kawasan yang dahulunya dipegang oleh parti Melayu akhirnya bertukar milik dan diterajui oleh parti berasaskan bangsa Tionghoa. Tiada wakil rakyat yang bertanggungjawab tampil menyelesaikan masalah penduduk kampung. Mainan politik menyebabkan rakyat hilang maruah. Hal ini seperti yang selalu dikatakan oleh Mak Som, salah satu watak dalam novel ini, tanah merupakan maruah, bangsa yang tidak bertanah merupakan bangsa yang bangsat. Sikap negatif Tan Sri Dahan sebagai pemimpin yang tidak bertanggungjawab dilihat melalui petikan berikut:

"Well, memang itu pun kemungkinannya kalau terjadi begitu, lebih mudah misi kita.Perpecahan pemilik tanah bermakna mereka tiada kesepakatan. 
Tiada persefahaman bermakna mereka tiada suara yang kuat. Kita mesti melemahkan semaksimum mungkin kekuatan mereka. Apabila mereka bersatu, kita pula celaru nanti”, Tan Sri Dahan meneruskan kuliah politik tidak rasminya untuk Dato' Mahfus. Sesekali Tan Sri Dahan tersenyum sambil menggeleng-geleng kepalanya sedikit kerana melihat Dato' Mahfus masih naif dalam langkah bisnes dan politiknya.

(Nenek, 2014, p. 119)

Oleh hal yang demikian, konflik kepimpinan ini selari dengan pendapat Maslow (1970), yang mengatakan bahawa jaminan keselamatan penting untuk kesejahteraan hidup rakyat. Sebagai pemimpin politik seharusnya sentiasa mencari jalan untuk menjaga keselamatan anak buahnya. Walau bagaimanapun sebaliknya yang berlaku, sikap tamak Tan Sri Dahan yang terlalu mengejar kemewahan untuk diri sendiri sehingga gagal menjalankan amanah sebagai pemimpin politik. Sikap Tan Sri Dahan yang tidak bertanggungjawab dan mementingkan diri sendiri telah mencetuskan konflik dalam pimpinan politik.

\section{Konflik Keluarga}

Perbincangan Perbincangan konflik ini diperluas dengan konflik dalam institusi kekeluargaan. Menurut Fatimah Abdullah (2015, p. 1), keluarga selalu dirujuk sebagai satu kelompok sosial yang tinggal bersama, menguruskan ekonomi bersama, melaksanakan fungsi reproduksi, di samping mendidik anak-anak. Sebuah keluarga biasanya terdiri daripada pasangan suami isteri serta dengan seorang atau beberapa orang anak mereka, termasuk juga anak angkat.

Rozumah dan Rumaya (2002, p. 4) melihat definisi keluarga berdasarkan perspektif Islam dengan mengatakan bahawa keluarga ialah struktur istimewa. Pertalian ahli keluarga melalui hubungan darah atau hubungan perkahwinan; hubungan ini merangkumi elemen saling mengharap dan saling membantu seperti yang digariskan dalam agama, undang-undang dan dihayati oleh setiap ahlinya.

Burges dan Locke (1953) dalam Rozumah dan Rumaya (2002, p. 4) mendefinisikan keluarga sebagai sekumpulan orang yang mempunyai hubungan darah atau diangkat, mendiami satu isi rumah, berinteraksi dan berkomunikasi antara satu sama lain menerusi peranan masing-masing sebagai suami isteri, ibu-anak, anak lelaki-anak perempuan, adik-beradik mereka cipta dan mengekalkan budaya yang sama. 
Berdasarkan penelitian, Razali Endun menerusi novel Nenek (2014) mengetengahkan konflik yang wujud dalam sesebuah keluarga. Konflik ini berlaku disebabkan sikap anak yang mengabaikan tanggungjawab terhadap ibu bapa. Menurut Zarinah (2007, p. 235) pengabaian dapat ditakrifkan sebagai penolakan atau kegagalan untuk memenuhi sebarang tanggungjawab yang diamanahkan kepada seseorang penjaga. Ibu bapa yang sudah tua dibiarkan sendirian, sedangkan anak-anak mereka ada yang berpangkat dan bergaji besar.

Dalam novel Nenek karya Razali Endun (2014), fenomena pengabaian anak terhadap bapa dapat dilihat melalui gambaran watak Tok Nenggal. Setelah kedua-dua orang anaknya berkahwin, Tok Nenggal dibiarkan tinggal sendirian sehingga makan minumnya tiada siapa yang peduli. Konflik tersebut dapat dilihat melalui petikan berikut:

Dua orang anak Tok Nenggal sudah besar dan berumah tangga. Cucunyacucunya hanya sesekali datang ke rumahnya apabila cuti sekolah.Tok Nenggal duduk seorang diri siang malam. Makan minum tidak terjaga.

(Nenek, 2014, p. 189)

Kasih sayang yang diterima akan menjadikan kehidupan manusia lebih sempurna. Hal ini dinyatakan oleh Maslow (1970) bahawa untuk memenuhi keperluan kasih sayang, manusia memerlukan hubungan dengan insan lain seperti ahli keluarga, sahabat, masyarakat dan sebagainya. Gambaran ini dijelaskan melalui watak Tok Nenggal yang memerlukan kasih sayang daripada anak-anaknya. Kasih sayang merupakan elemen penting bagi mencapai tahap kesempurnaan kendiri. Namun begitu, sikap anak-anak Tok Nenggal yang telah mengabaikannya telah menyebabkan Tok Nenggal tidak dapat mencapai tahap tersebut seperti yang telah disarankan oleh Maslow.

Hal ini juga bersesuaian dengan penyataan yang dikemukakan oleh Mazilan Musa (2011) dalam Khadijah Alavi (2012, p. 47) bahawa dalam Islam penjagaan kedua-dua ibu bapa pada peringkat usia tua merupakan tanggungjawab yang perlu dipikul oleh anak-anak.

\section{Konflik Ekonomi}

Kehidupan bermasyarakat yang sentiasa mengalami perubahan telah menyumbang terjadinya konflik, terutamanya dalam bidang ekonomi. 
Konflik ekonomi dalam kajian ini akan dipecahkan kepada dua, iaitu pembangunan ekonomi dan masalah kemiskinan.

\section{(1) Pembangunan sosioekonomi}

Definisi pembangunan seperti yang dinyatakan oleh Andrew 1996 dalam Arba'ie, Nik Rafidah dan Asiah (2001, p. 206) bukan sahaja melibatkan aspek fizikal tetapi juga spiritual. Realitinya, pembangunan mendatangkan kesan negatif dan positif kepada rakyat.

Pembangunan mempunyai pelbagai maksud dan dimensi. Biasanya, pembangunan merujuk usaha mengubah masyarakat atau negara daripada keadaan mundur kepada maju. Perubahan yang dimaksudkan meliputi pelbagai aspek kehidupan manusia seperti ekonomi, politik, sosial, pendidikan, psikologi dan sebagainya. Selain itu, pembangunan juga merujuk aspek fizikal, kebendaan dan bukan kebendaan. Secara keseluruhannya, pembangunan ekonomi negara yang seimbang menjadi matlamat dalam penggubalan dasar pembangunan ekonomi negara sejak kemerdekaan sehingga kini (Hasnah dan Mardiana, 2007, p. 268).

Menurut Asan Ali (2004, p. 2), pembangunan dapat didefinisikan sebagai proses peralihankehadapan kepadakeseluruhan sistem sosialseperti peningkatan produktiviti, keseimbangan ekonomi, sosial, pengetahuan moden, kewujudan institusi moden dan peralihan kepada sikap yang lebih baik. Pembangunan juga dilihat sebagai proses transformasi ekonomi berasaskan pertanian kepada ekonomi yang berasaskan perindustrian dan perkhidmatan.

Konflik pembangunan sosioekonomi orang Melayu berpunca daripada sikap mereka yang hanya bergantung pada satu sumber sahaja. Mereka juga tidak berusaha mencari alternatif lain apabila pekerjaan yang diusahakan mengalami masalah atau tidak berjaya. Selain itu, mereka mudah bersyukur dengan apa yang ada. Konflik pembangunan ekonomi orang Melayu dilihat melalui petikan di bawah:

Petani Melayu biasanya hanya mengharapkan kepada satu sumber tanpa berikhtiar mencari rezeki sampingan. Mereka mudah bersyukur dengan apa yang mereka nampak. Kalau segantang sudah mencukupi, tidak payah menjadikan seguni. Konsep ini tidak akan membangunkan ekonomi. Orang Melayu akan sentiasa terasa menumpang di negerinya sendiri.

(Nenek, 2014, p.136) 
Situasi ini jelas dinyatakan oleh Nik Rafidah Nik Muhamad Affendi (2016) bahawa punca kemiskinan masyarakat tani mempunyai kaitan rapat dengan sikap petani yang terlalu bergantung pada sektor pertanian sahaja. Sikap orang Melayu yang hanya bergantung pada satu sumber sahaja menyebabkan ekonomi orang Melayu mundur berbanding dengan kaum lain. Situasi ini bersesuaian dengan teori humanistik Maslow (1970) yang menegaskan bahawa manusia memerlukan kestabilan kerja bagi meneruskan kelangsungan hidup. Ekonomi yang stabil dalam sesebuah keluarga dapat menjamin keselamatan kepada anggota keluarga.

Selain itu, konflik pembangunan ekonomi juga menyebabkan penduduk kampung tidak mampu memiliki rumah sendiri. Mak Som mengemukakan cadangan semasa rundingan agar menyediakan harga rumah yang mampu dimiliki oleh penduduk kampung bagi mengatasi konflik yang dialami oleh penduduk di kampung tersebut. Hal ini dapat dijelaskan melalui petikan berikut:

\footnotetext{
"Kami menuntut supaya pemaju membina rumah yang mampu kami miliki. Beri peluang kepada kami orang miskin dan marhean memiliki rumah agar kami tidak terpinggir di bumi sendiri. Kami juga berhak memiliki rumah dalam proses pembangunan yang dirancang," sambung Mak Som.
}

(Nenek, 2014, p. 132)

Oleh hal yang demikian, konflik pembangunan sosioekonomi yang dialami oleh penduduk kampung ini bersesuaian dengan teori humanistik Maslow (1970) yang mengatakan bahawa manusia memerlukan tempat tinggal sebagai tuntutan fisiologi. Konflik yang dihadapi oleh penduduk kampung adalah kerana mereka dizalimi pihak pemaju yang tidak memberikan peluang kepada mereka untuk memiliki rumah yang akan dibangunkan di atas tanah mereka sendiri. Hal ini juga bersesuaian dengan pendapat Norzalinda (2006, p. 119) yang mengatakan bahawa kemiskinan juga boleh mengakibatkan ketidakmampuan memiliki rumah sendiri.

Di samping itu, konflik juga tercetus setelah kawasan tersebut dibangunkan sebagai kawasan industri. Pembangunan tersebut memberikan kesan negatif kepada penduduk kampung. Kawasan hutan gelam yang pada asalnya menjadi habitat flora dan fauna bertukar wajah dan dibangunkan sebagai kawasan perindustrian. Kawasan tersebut menjanjikan peluang pekerjaan kepada orang ramai, tetapi malangnya rakyat tempatan tidak dapat menikmati pembangunan di kampung mereka apabila pihak pengilang 
membawa masuk warga asing untuk dijadikan pekerja. Nasib penduduk tempatan begitu malang kerana pihak pengilang lebih memberikan keutamaan kepada warga asing. Pengilang membayar upah yang murah kepada warga asing berbanding dengan penduduk setempat. Keadaan ini menguntungkan pengilang. Nasib penduduk kampung Bertam Malim seakan-akan tidak terbela. Kawasan kampung mereka dibangunkan sebagai kawasan perindustrian yang menjanjikan peluang pekerjaan, tetapi mereka tidak dapat menikmati peluang tersebut. Mereka seperti merempat di tanah air sendiri. Fenomena tersebut dibuktikan melalui petikan berikut:

Di atas tanah hutan gelam itulah sekarang didirikan berpuluh-puluh kilang. Ada pelbagai kilang dibina di situ, daripada berstatus kecil, sederhana hingga ke taraf gudang besar. Perusahaan di situ memang menjana ekonomi dan memberi pekerjaan kepada orang ramai. Sayangnya, yang ramai bekerja di situ bukan orang tempatan tetapi rakyat asing yang dibawa masuk baik secara sah mahupun secara haram. Jumlah mereka meningkat setiap bulan kerana banyaknya pengilang yang memerlukan tenaga kerja murah.

(Nenek, 2014, p. 228)

Fenomena ini juga dipersetujui oleh pakar ekonomi Pusat Pengajian Ekonomi, Kewangan dan Perbankan, Universiti Utara Malaysia, Amir Hussin Baharuddin dalam Sinar Online 10 Mac 2015. Menurut beliau, memang tidak dapat dinafikan banyak sektor seperti industri binaan, perladangan dan perkhidmatan berkemungkinan lumpuh sekiranya Malaysia tidak mempunyai tenaga buruh murah. Namun begitu, jumlah buruh asing di Malaysia terlalu tinggi. Bukan semua sektor memerlukan khidmat buruh asing. Oleh hal yang demikian, bagi mengurangkan kadar kemasukan buruh asing ke negara ini perlu ditubuhkan undang-undang bagi mengehadkan sektor-sektor pekerjaan yang boleh diceburi pekerja asing. Selain itu, pihak korporat juga perlu mengutamakan rakyat tempatan dengan memberikan kadar upah yang sesuai.

Oleh hal yang demikian, Abraham Maslow (1970) telah menegaskan bahawa manusia memerlukan kestabilan kerja bagi menjamin kesejahteraan hidup. Sikap pemaju yang tidak bertanggungjawab telah menyebabkan penduduk setempat hilang punca pendapatan. Hal ini jelas dinyatakan oleh Rosnani dan Nik Rafidah (2017) bahawa kampung tersebut terus mambangun, tetapi masyarakat berada dalam kedaifan dalam pelbagai aspek kehidupan. 


\section{(2) Kemiskinan}

Konflik ekonomi yang berlaku juga akan menyumbangkan masalah kemisikinan. Walaupun negara ini sedang membangun, namun pada hakikatnya masih ramai rakyat Malaysia yang berada di bawah paras kemiskinan terutamanya di luar bandar. Menurut Norazit Selat (1993, p. 71) kemiskinan merupakan suatu konsep yang relatif. Taraf hidup seseorang dikatakan rendah atau miskin apabila dibandingkan dengan taraf hidup orang lain. Islam juga tidak memandang suci kepada kemiskinan, malah memandangnya sebagai penyakit yang berbahaya (Haron, 2007, p. 90). Menurut Mahmood Zuhdi dalam Haron (2007, p. 90) Rasulullah SAW pernah bersabda "kemiskinan boleh membawa kepada kekufuran". Oleh hal yang demikian, masalah kemiskinan perlu dihapuskan. Dalam hubungan ini, baginda Rasulullah SAW pernah menegaskan kalaulah kemiskinan itu diibaratkan sebagai manusia, sudah tentu baginda akan membunuhnya.

Sehubungan dengan itu, isu kemiskinan perlu ditangani bagi mengelakkan masyarakat menjadi kufur. Bagi menangani masalah kemiskinan, punca dan sebab haruslah diketahui terlebih dahulu. Oleh itu, dalam konteks kajian ini, pengkaji akan memperlihatkan fenomena kemiskinan dalam novel Nenek karya Razali Endun. Isu kemiskinan ini dikaitkan dengan pembangunan yang tidak terancang.

Dalam novel Nenek karya Razali Endun (2014), fenomena kemiskinan berlaku kerana daya pengeluaran padi yang rendah dalam kalangan petani. Pembinaan kawasan perumahan di kampung tersebut telah menyebabkan bekalan air tidak dapat disalurkan ke kawasan sawah. Oleh hal yang demikian, penduduk kampung tidak dapat mengusahakan tanaman padi.

Tanah sawah itu sudah tidak dikerjakan lagi oleh orang kampung semenjak taman perumahan dibina di lereng dan di atas bukit di kampung itu. Pembangunan projek perumahan itu menyebabkan bekalan air tidak masuk ke situ.Lama-kelamaan paras sawah menjadi lebih tinggi berbanding tali air menyebabkan bekalan tidak dapat masuk ke situ.Sawah menjadi kontang dan mula terbiar begitu sahaja sedikit demi sedikit tanpa diusahakan. Masalah itu berlaku kira-kira 17 tahun lalu.Ketika itu Haji Kiran masih hidup.Keadaan tidak memberangsangkan itu memudaratkan minat penduduk kampung untuk terus mengusahakan sawah.Haji Kiran dan Mak Som juga begitu.Patah semangat melihat tanah sawah yang kontang itu.

(Nenek, 2014, p. 05) 
Menurut Abd. Malik (1996) dalam Norzalinda (2006, p. 118) punca kemiskinan penduduk kampung adalah kerana daya dan jumlah pengeluaran padi yang rendah dalam kalangan petani.

Selain itu, tanaman padi yang tidak dapat diusahakan meningkatkan kadar pengangguran di Kampung Bertam Malim. Bagi penduduk kampung, jumlah wang lima ratus ringgit yang diberikan oleh Syarikat Padu Menang Sdn. Bhd. amat bermakna buat mereka. Oleh sebab pertanian sawah padi tidak dapat diusahakan, rata-rata penduduk kampung menjadi penganggur.

Beberapa orang bertepuk tangan.Yang paling kuat menepuk ialah Mat Dali dan Samad Betawi.Mereka kelihatan masih terlalu gembira menerima habuan wang sagu hati tadi.Lima ratus ringgit bagi mereka amat bermakna, apalagi setelah tanah sawah itu tidak dapat dikerjakan, lama mereka menganggur. Kalau ada kerja pun, tidak tetap.Pendapatan tidak seberapa.Justeru, wang ihsan itu ibarat tikaman loteri bagi mereka.

(Nenek, hlm.127)

Kemiskinan penduduk semakin meningkat kerana pengusaha dan pihak berwajib tidak memberikan peluang pekerjaan kepada mereka. Hal ini digambarkan oleh watak Tok Nenggal yang berusaha mencari kerja. Malang bagi Tok Nenggal faktor usia menyebabkannya tidak mendapat pekerjaan. Tok Nenggal juga tidak dapat meneruskan kemahiran bertukang kerana masyarakat sudah tidak berminat dengan rumah kayu.

Usaha Tok Nenggal untuk mendapat sebarang kerja yang bersesuaian di salah satu kilang di situ menghampakan.Tauke kilang menolak permohonan Tok Nenggal kerana usianya. Tok Nenggal tidak ada pilihan, kecuali menyandarkan harapannya kepada kemahiran bertukang. Namun, siapakah yang berminat membina rumah kayu lagi sekarang?

(Nenek, 2014, p. 228)

Selain itu, Samad Betawi juga tidak dapat meneruskan perusahaan dan tempe kerana kekurangan modal. Kemiskinan menghalang Samad Betawi untuk menyewa kilang tersebut dengan kadar sewa RM5000 sebulan dan deposit sebanyak tiga bulan.

Samad Betawi bercadang menyewa kilang kecil di situ untuk perusahaan tempe dan keropoknya. Malang. Dia tidak mampu kerana sewanya terlalu 
mahal. Ruang seluas 15 x 40 kaki sewanya sehingga RM5,000 sebulan. Itu tidak termasuk syarat menyertakan deposit sebanyak tiga bulan.

(Nenek, 2014, p. 228)

Hal ini dinyatakan oleh Maslow (1970) bahawa manusia amat memerlukan kestabilan kerja bagi menjamin keselamatan hidup. Konflik yang dialami oleh masyarakat menyebabkan mereka tidak dapat menjana pendapatan ekonomi keluarga. Konflik kemiskinan yang dialami oleh penduduk kampung tersebut dilihat melalui pendapat yang dinyatakan oleh Tuan Pah Rokiah Syed Hussain dan Hamidi Ismail:

Kemiskinan merupakan salah satu isu penting yang perlu diberikan tumpuan utama dalam agenda pembangunan negara. Masalah kemiskinan yang membelenggu penduduk boleh menyebabkan kehidupan mereka terseret jauh ke lubuk kedaifan, kemunduran, ketidakseimbangan ekonomi, sosial, politik, taraf pendidikan, dan kesejahteraan hidup.

(Tuan Pah Rokiah \& Hamidi, 2002, p. 41)

Sehubungan itu, perkara ini telah disedari lama sebelum novel ini diterbitkan, iaitu Rancangan Malaysia Ketiga (1976) lagi telah dijelaskan bahawa punca kemiskinan adalah disebabkan oleh kurangnya peluang pekerjaan yang produktif seperti pekerjaan yang berkaitan dengan pentadbiran dan pengurusan, jualan, iktisas, teknikal, pengeluaran dan sebagainya (Norazlinda, 2006, p. 118). Walau bagaimanapun, sehingga kini masalah ini masih wujud.

\section{Konflik dalam Diri}

Manusia juga kadang-kadang berkonflik dengan diri sendiri. Konflik dalaman individu ini berlaku kerana emosi yang tidak dapat dikawal. Oleh sebab terlalu mengikutkan emosi dan kehendak hati bagi mencapai cita-cita yang diinginkan, ada manusia yang sanggup memilih jalan yang salah. Namun demikian, setelah berada di kemuncak kejayaan manusia akan berasa serba salah dan ingin kembali ke pangkal jalan. Hal ini dapat dilihat melalui gambaran watak Mahfus yang berasa serba salah kerana telah terlalu banyak terhutang budi dengan Tan Sri Dahan. Segala kemewahan yang dimiliki oleh Mahfus semuanya kerana budi yang ditaburkan oleh Tan Sri Dahan. Situasi tersebut menyebabkan Mahfus berkonflik dengan dirinya sendiri 
setelah menyedari bahawa sudah banyak dia terhutang budi dengan Tan Sri Dahan. Pergelutan emosi Mahfus dapat dilihat melalui petikan di bawah:

Mahfus serba salah. Memang dia sudah banyak terhutang budi kepada Tan Sri Dahan tetapi kalau boleh dia mahu mengehadkan rasa keterikatan itu. Dia sedar ada bahayanya jika terlalu bergantung dengan seseorang. Bukannya dia tidak teringin mendapat gelaran.Ia perkara biasa dalam dunia sekarang. Mahfus juga sedar ada orang yang sanggup mengeluarkan wang yang banyak untuk "membeli" pingat kebesaran kerana mahu bermegah dengan gelaran itu.

(Nenek, 2014, p.76)

Oleh hal yang demikian, konflik dalam diri yang berlaku terhadap Mahfus bersesuaian dengan teori humanistik Maslow (1970) mengatakan bahawa manusia memerlukan penghargaan diri. Manusia juga inginkan status dalam hidup. Namun demikian, jalan yang diambil oleh Mahfus adalah salah. Oleh sebab inginkan status dan ingin dipandang tinggi dalam masyarakat, Mahfus sanggup mengorbankan tanah penduduk kampung. Namun akhirnya, kedudukan dan pangkat yang dimiliki telah menjerat dirinya.

Konflik dalaman yang dialami oleh Mahfus ini ditegaskan oleh Syed Othman Alhabshi dan Nik Mustapha (1994, p. 29) dengan mengatakan bahawa "manusia yang terlalu mengejar duniawi boleh jadi gila pangkat, gila kuasa, gila pengaruh dan gila nama".

\section{KESIMPULAN}

Novel Nenek karya Razali Endun mengungkapkan realiti masyarakat apabila menyentuh pelbagai konflik yang melingkari kehidupan masyarakat kampung. Persoalan kemanusiaan berjaya diungkapkan oleh pengarang dalam novel tersebut. Setiap konflik yang tercetus merupakan realiti masyarakat. Perkara ini dikemukakan oleh pengarang untuk memberikan kesedaran kepada masyarakat. Konflik dalam politik berlaku kerana sikap ahli politik yang mementingkan diri, sikap tamak, mengejar kemewahan, dan sebagainya sehingga memberikan kesan yang mendalam kepada kehidupan masyarakat di kampung tersebut. Konflik kekeluargaan terjadi kerana sikap anak-anak yang suka mengabaikan tanggungjawab terhadap ibu bapa. Sikap golongan kapitalis yang suka menindas golongan yang lemah telah menyebabkan masyarakat berada dalam belenggu ekonomi yang memberikan kesan 
keseluruhan dalam kehidupan mereka. Konflik dalaman pula tercetus apabila manusia berperang dengan dirinya sendiri yang mewujudkan perasaan serba salah apabila keinginan telah dicapai. Konflik-konflik yang berlaku ini merupakan satu tindakan manusia yang ingin memenuhi kehendak masingmasing. Dalam usaha memenuhi kehendak hati tidak semua manusia akan berjaya, pasti akan ada konflik yang tidak diinginkan berlaku. Rumusan daripada kajian ini mendapati novel Nenek karya Razali Endun mampu memberikan gambaran tentang masyarakat kontemporari. Isu dan konflik yang dikemukakan menggambarkan realiti sezaman dan menyeluruh. Kematangan pengarang menghuraikan kisah masyarakat dan kebijaksanaan dalam penyelesaian konflik telah membuktikan kemampuan Razali Endun dalam penghasilan naskhah yang terbaik kepada khalayak pembaca. Oleh itu, tidak hairanlah novel ini berjaya merangkul Hadiah Sastera Perdana Malaysia pada tahun 2014.

\section{RUJUKAN}

Arba'ie Sujud, Nik Rafidah Nik Muhammad Affendi dan Asiah Abdul Rahman. (2011). Sastera Melayu suatu pengantar. Kuala Lumpur: Tinta Press Sdn. Bhd. Asan Ali Golan Hassan. (Okt-Dis 2004). Falsafah Pembangunan Pemimpin. Pemikir 38, 02. Kuala Lumpur: Utusan Karya Sdn. Bhd.

Asmawati Desa. (2002). Psikologi untuk golongan profesional. McGraw Hill

Azizi Yahaya, Jaafar Sidek Latif. (2009). Membentuk identiti remaja. PTS Professional Publishing Sdn. Bhd.

Fatimah Abdullah. (2015). Keluarga dan permodenan di Malaysia. Kuala Lumpur: PTS Publications \& Distributions Sdn.Bhd.

Fatimah Daud. (1992). Pengenalan teori-teori sosiologi. Kuala Lumpur: Penerbitan Fajar Bakti Sdn. Bhd.

Hasnah Hussin dan Mardiana Nordin. (2007). Pengajian Malaysia. Kuala Lumpur: Oxford Fajar Sdn Bhd.

Haron Din. (2007). Agama bisnes \& pengurusan. Kuala Lumpur: PTS Publications $\&$ Distributions Sdn. Bhd.

Ishak Saat. (2009). Malaysia 1945-2000. Kuala Lumpur: Utusan Publications Distributors.

Khadijah Alavi. (2012). Dilema penjagaan ibu bapa tua. Bangi: Universiti Kebangsaan Malaysia.

Mahmood Nazar Mohamed. (1990). Pengantar psikologi: satu pengenalan asas kepada jiwa dan tingkah laku manusia.Kuala Lumpur: Dewan Bahasa dan Pustaka.

Maslow, Abraham, H. (1970). Motivation and personality. New York: Harper \& Row Publishers. 


\section{MALAY LITERATURE VOLUME 31 NUMBER 1 JUNE 2018}

Mohd Foad Sakdan. (2005). Pengurusan konflik. Kuala Lumpur: Dewan Bahasa dan Pustaka.

Mohammed Sani Ibrahim, Jamalul Lail Abdul Wahab. (2012). Kepimpinan pendidikan. Bangi Universiti Kebangsaan Malaysia.

Moleong, Lexy J. (2004). Metodologi penelitian kualitatif. Bandung: Remaja Rosdakarya.

Nik Rafidah Nik Muhamad Affendi. (2016). Ekspresi psikologi dalam novel pilihan. Universiti Malaysia Terengganu: Penerbit UMT.

Norazit Selat. (1993). Konsep asas antropologi. Kuala Lumpur: Dewan Bahasa dan Pustaka.

Nor Raudhah Haji Siren. (2006). Falsafah diri remaja dalam novel remaja Melayu. Perpustakaan Kuala Lumpur: Cawangan Taman Tun Dr Ismail.

Norazlinda Mohd Ali Hanafiah. (2006). Memahami kemiskinan dalam isu-isu pendidikan kerja sosial, Azlin Hilma Hillaluddin, Fatimah Zailly Ahmad Ramli, Rasimah Sayuti dan Yusmarhaini Yusof(ed). Sintok: Universiti Utara Malaysia.

Razali Endun. (2014). Nenek. Kuala Lumpur: ITBM.

Robiah K. Hamzah. (2004). Teknik dan strategi membimbing remaja kepimpinan. Kuala Lumpur: Percetakan Cergas Sdn. Bhd.

Rosnani Md Zain, Nik Rafidah Nik Muhamad Affendi. (2017). ' Fenomena Sosial dalam Novel Nenek karya Razali Endun”. Jurnal PENDETA 8. Penerbit Universiti Perguruan Sultan Idris.

Rozumah Baharudin, Rumaya Juhari. (2002). Pengantar perkahwinan dan keluarga. Serdang: Universiti Putra Malaysia.

Sinar Online. (2015). Kawal lambakan pekerja asing di Malaysia. www.sinarharian. com.my/.../kawal-lambakan-pekerja-asing-di-malaysia....

Syed Othman Alhabshi, Nik Mustapha Nik Hassan. (1994). Islam and tolerance. Kuala Lumpur: Institut Kemahiran Islam Malaysia.

Tuan Pah Rokiah Syed Hussain dan Hamidi Ismail. (2002). "Kemiskinan di Malaysia: Isu dan Cabaran". Impak pembangunan kualiti hidup dan persekitaran. Kuala Lumpur: Utusan Publications \& Distributors Sdn. Bhd.

Ting Chew Peh. (1997). Konsep asas sosiologi. Kuala Lumpur: Dewan Bahasa dan Pustaka.

Zarinah Arshat (2008). Isu keluarga kontemporari. Kuala Lumpur: Inreach Edition.

Received: 20 March 2018

Accepted: 12 May 2018 